\title{
Strength Analysis and Assessment of Ina-TEWS Wave Glider
}

\author{
Kusnindar Priohutomo ${ }^{*}$, Wibowo Harso Nugroho² iD \\ ${ }^{I}$ Indonesian Hydrodynamics Laboratory, Surabaya, Indonesia \\ ${ }^{2}$ Centre for Maritime Industry Engineering Technology, Surabaya, Indonesia \\ *Corresponding author: kusnindar.priohutomo@gmail.com
}

\begin{abstract}
Indonesia as a country that often experiences tsunami disasters needs to have an early warning system against tsunami disasters. This system can use various existing technologies, one of which is the tsunami buoy system. The new tsunami buoy system does not use the natural mooring system but uses the wave glider system. This paper discusses the structural strength of the surface floater of wave glider using Eva Foam and Fiberglass material for skin and Alluminium material for frame and kell. The surface floater using 16 pieces for frame and 1 piece for keel. Enviromental loads is use in this paper like hydrodynamics load and weight load. The results from this paper is material from Eva Foam has a maximum principle stress is $12693 \mathrm{~Pa}$ and shear stress is $6114.6 \mathrm{~Pa}$. For material from Fiberglass has maximum principle stress is $11.875 \mathrm{~Pa}$ and shear stress is $6076.3 \mathrm{~Pa}$. Safety factor (SF) from maximum principle stress and shear stress for Eva Foams is up to $6 \mathrm{x}$ and $\mathrm{SF}$ for maximum principle and shear stress for Fiberglass is up to 26x. Conclusions for this paper is the desain for surface floater of wave glider it can be operated in the sea with draugh $0.18 \mathrm{~m}$.
\end{abstract}

Keywords:Indonesian Early Warning System; Wave Glider; Surface Floater; Maximum Principle Stress; Safety Factor

$\begin{array}{lll}\text { History: } & & \text { Publisher: Undiksha Press } \\ \text { Received } & : 24 \text { August } 2020 & \text { Licensed:This work is licensed under } \\ \text { Revised } & : 1 \text { September } 2020 & \text { a Creative Commons Attribution 3.0 License } \\ \text { Accepted } & : 26 \text { September } 2020 & \end{array}$

\section{Introduction}

As a country that is located at the confluence of three plates, namely the Eurasian plate, the Indoaustralian plate and the Pacific plate and is an area through which a series of active volcanoes or also called the ring of fire has the potential for disasters, especially earthquakes at sea and resulting in a tsunami. The tsunami disaster that occurred in September 2018 caused deep injuries and became a national disaster which resulted in 2,101 people died, 1,373 people disappeared and 206,219 people were displaced. In addition, at the end of 2018 in December there was a tsunami in the Sunda Strait that hit Banten and Lampung Provinces (Atika et al., 2019).

For that, Agency for The Assessment and Application of Technology (BPPT) designing Indonesian Tsunami Early Warning System (Ina-TEWS) which will later be installed in places that are predicted to be affected by a tsunami wave. This program is a research program at BPPT that involves various scientific competencies, from marine engineering, material engineering, electronic engineering, mechanical engineering and various techniques that support the Ina-TEWS design process. The new design of the InaTEWS is use the wave glider type. Wave Glider type is the newest type of various types for existing tsunami buoy. 
Wave glider now is widely used for exploration of marine resources and marine topography. A wave glider is an unmanned vehicle that combines two bodies (floater and submerged glider) via flexible umbilical cables, which can directly convert the movement of ocean waves into propulsion, and also overcome the need for low energy consumption during the observation period at sea. (Zhang et al., 2020). Wave gliders have been widely researched and published by papers, among others (Olson, 2012)which examines the working principle of the sensors used in wave gliders. In this paper, the wave glider is divided into two parts, namely the subsurface (propulsion unit) which converts the thrust from the up and down movement of ocean waves. The second part is a floater that is connected to the subsurface using an umbilcal cable. On the floater there are several electronic equipment including solar power panels, antenna decks, mission payloads, core electronics modules. The floater is made of foam material covered with fiberglass. Wave gliders can be used for various needs, including for surveys, monitoring events, changing buoys and for communication gateways. The conclusion of this paper is the communication architecture wave glider can be used for various needs. A more specific requirement is the ability to send data without debugging (delay) as a result of the environment with minimal changes.

Next paper discuss about wave glider is (Yu et al., 2016) who researched the wave glider which functions as a marine mobile buoy (MMB) which has many potential uses in the maritime industry and marine research. For the propulsion system, the Suntory Mermaid II system is used, which was first popularized by the Suntory Mermaid Ship. The conclusion of this paper is that the propulsion mechanism as the main mover always produces thrust under any floating body movement conditions, the dynamic model of the propulsion mechanism shows the relationship between the heave movement of the buoy, stiffens and thrust, for maximum movement of the angle of attack (angle of attack). attack) of the foil that produces the greatest thrust is $0.3 \mathrm{rad}$.

Another paper that discusses wave gliders is (Wang et al., 2019) which discusses the use of a wave glider as a wave powered autonomous marine vehicle which consists of a submerged glider that is connected to a surface floater with a tether connector. In this paper, the study focuses on the movement of a 4 degrees of freedom (4-DOF) mathematical model of the wave glider using the Newton-Eular approach. For horizontal waves using second order wave drift, while for vertical waves using first order wave force. Furthermore, the mathematical equation is used for the calculation of the motion simulation of the wave glider. The results of this paper are the calculation of the movement of the 4-DOF wave glider in various wave conditions and produce several recommendations, including the shorter tether length, which will reduce the resistance of the foil, the weight of the surface float and submarine glider models is made lighter in order to further improve the resistance. the energy the waves produce.

Because wave gliders operate in the high seas, the material used for surface floaters must have the strength to withstand the forces of ocean waves. For this reason, a reference is needed to design or analyze the strength of the surface floater material. Some of the existing papers discuss the structural strength of the ship, including the paper belonging to it (Xie et al., 2020) Where in his research, he examines the response of the hull structure when the ship experiences a slamming load. Initial investigation of the response of the hull structure using the CFD method in which the slamming load is divided into three types of loads (vertical, horizontal and roll). Numerical prediction (numerical simulation) is used as the initial calculation which will later be compared with the experimental results. The conclusion of this research is to predict slamming load, the ratio between the minimum mesh size and body size must be less than 0.004 . Numerical verification for vessels such as the section entering water with heel angle has a maximum error rate of $8 \%$. 
The next paper that discusses the strength of the ship's structure is (Liu and Guedes Soares, 2020) where the research is focused on the structure of the hull of the ship due to the load or the moment of hogging and sagging movements due to sea waves. The initial approach is to calculate the structural strength of the "cyclic ultimate strength". For numerical calculations using the LS-Dyna software. Numerical analysis on the cyclic ultimate structure considers the bauschinger effect on steel. The Bauschinger effect describes the flow of stress decreasing when the load is reversed. The bauschinger effect is mostly found in conventional steels but also in high strength steels. The conclusion of this study is that ship hull girders have a smaller ultimate strength due to cyclic loads. The value of the difference in ultimate strength of steel that is subjected to cyclic loads and steel that experiences a static load is $10 \%$.

The next paper that discusses the strength of the ship's structure is (Mujahid and Priohutomo, 2018) which examines the shear stress on the Bore Hull Mining (BHM) type ship. BHM ships are vessels used to mine rocky materials in rivers. In this paper, the discussion focuses on the shear strength of BHM ships due to the heavy load of the ship. The calculation uses the numerical method with the Finite Element Method (FEM). The results of this paper are that the shear stress at various loading conditions is not suitable or does not meet the criteria set by Internatioanl Maritime Organization (IMO) dan Biro Klasifikasi Indonesia (BKI).

From the various references available, the authors focus their research on the strength of the material used as a hull on the surface floater wave glider. Where there are two types of material that will be used as the hull skin of the surface floater, namely EVA FOM and Fiberglass. To calculate the strength of the material using the Finite Element Method with FEM analysis software.

\section{Materials and Methods Material}

Ethylene Vinyl Accetate (EVA) Foam is a material that has the ability to absorb energy and force under various conditions and has a high tensile value (Areias et al., 2017)(Sang et al., 2016).EVA Foam in its application is often used in conjunction with polymer materials, including polycarbonate. With this mixture, the EVA material has better damping properties for sound insulation.

Fiberglass is a material from a composite type that has the advantage of being strong but still light in weight. Fiberglass is used for making boats, airplanes, car body or interior swimming pools and so on. In fiberglass composites, the reinforcing component is glass fibers and the binder is plastic (Salekeen and Jones, 2007)(Shen et al., 2017). The material properties for EVA Foam are shown in table 1 and the material properties for Fiberglass are shown in table 2.

Table 1. Material properties EVA Foam

\begin{tabular}{ccc}
\hline Parameter & Nominal & Unit \\
\hline Density & 30 & $\mathrm{~kg} / \mathrm{m}^{3}$ \\
Modulus Young's & $8 \times 10^{8}$ & $\mathrm{~Pa}$ \\
Poisson's Ratio & 0.4 & \\
Shear Modulus & $2.8 \times 10^{8}$ & $\mathrm{~Pa}$ \\
Tensile Yield Strength & 78000 & $\mathrm{~Pa}$ \\
Compressive Yield Strength & 780.000 & $\mathrm{~Pa}$ \\
\hline
\end{tabular}


Table 2. Material properties Fiberglass

\begin{tabular}{ccc}
\hline Parameter & Nominal & Unit \\
\hline Density & 2580 & $\mathrm{~kg} / \mathrm{m}^{3}$ \\
Modulus Young's & $7.23 \times 10^{10}$ & $\mathrm{~Pa}$ \\
Poisson's Ratio & 0.2 & \\
Shear Modulus & $3.01 \times 10^{10}$ & $\mathrm{~Pa}$ \\
Tensile Yield Strength & $3.44 \times 10^{6}$ & $\mathrm{~Pa}$ \\
Compressive Yield Strength & $3.00 \times 10^{6}$ & $\mathrm{~Pa}$ \\
\hline
\end{tabular}

Other materials are used as longitudinal reinforcement (keel) and transverse reinforcement (frame) so that the hull material does not experience deformation due to the load received. For the frame material used stainless steel is selected. This material was chosen with the consideration that it has a lighter weight when compared to steel or iron and also has resistance to seawater corrosion. Stainless Steel's material properties are shown in table 3 .

Table 3. Material properties Stainless Stell

\begin{tabular}{ccc}
\hline Parameter & Nominal & Unit \\
\hline Density & 2770 & $\mathrm{~kg} / \mathrm{m}^{3}$ \\
Modulus Young's & $7.1 \times 10^{10}$ & $\mathrm{~Pa}$ \\
Poisson's Ratio & 0.33 & \\
Shear Modulus & $2.6 \times 10^{10}$ & $\mathrm{~Pa}$ \\
Tensile Yield Strength & $3.1 \times 10^{8}$ & $\mathrm{~Pa}$ \\
Compressive Yield Strength & $2.8 \times 10^{8}$ & $\mathrm{~Pa}$ \\
\hline
\end{tabular}

\section{Main Dimension Surface Floater}

As one of the important elements in calculating the strength of the material with the load from ocean waves, determining the main size of the surface floater on the wave glider is important, besides being able to withstand wave loads, it must also be able to carry various electronic equipment used for data transmission needs, including solar. cell, antenna, battery and so on. The main surface floater sizes are shown in table 4.

Table 4. Main dimension surface floater

\begin{tabular}{ccc}
\hline Parameter & Nominal & Unit \\
\hline LOA & 3.050 & $\mathrm{~m}$ \\
$\mathrm{~B}$ & 0.760 & $\mathrm{~m}$ \\
$\mathrm{H}$ & 0.290 & $\mathrm{~m}$ \\
$\mathrm{~T}$ & 0.180 & $\mathrm{~m}$ \\
\hline Displacement & $\mathbf{1 7 3 . 4 6}$ & $\mathbf{k g}$ \\
\hline
\end{tabular}

\section{Hull Surface Floater}

The next step after determining the main dimensions is the process of drawing the surface flaoter using CAD software to make it easier. To make hull surface floaterusing Rhinoceros software which generates the sheer plan, half-breadth plan, body plan and isometric images shown in Figure 1. 


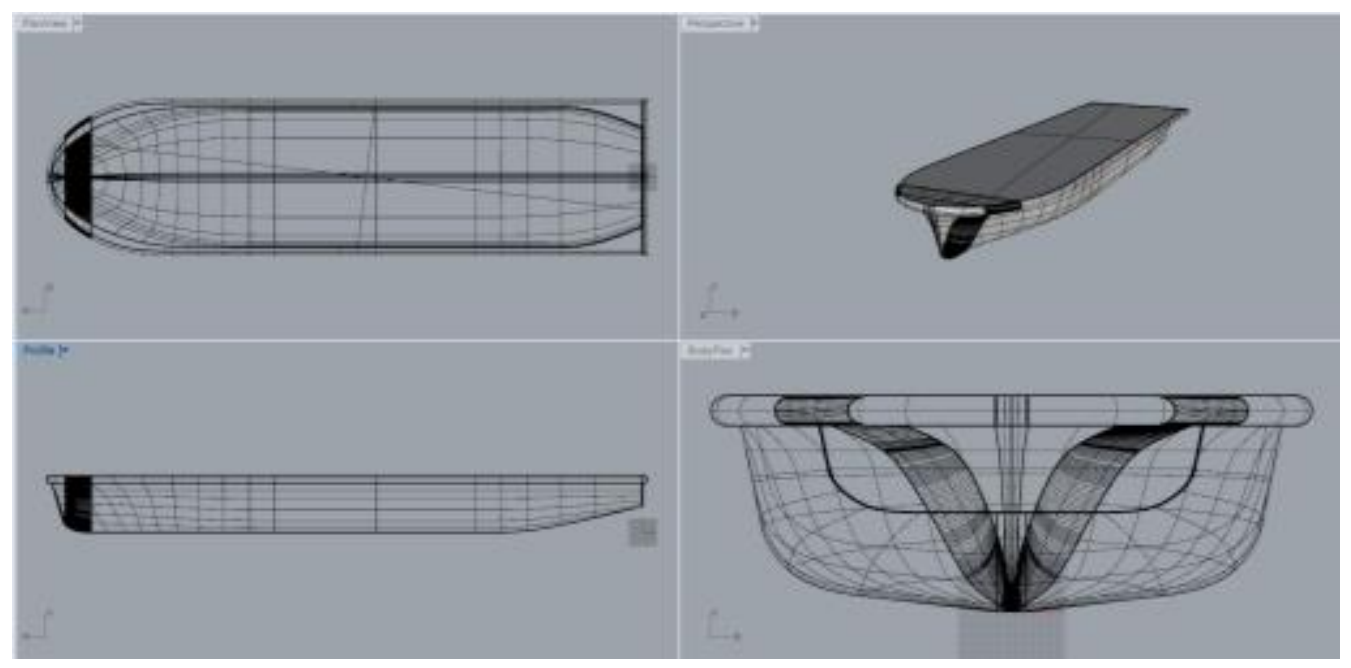

Figure 1. Hull Surface Floater

\section{Frame Surface Floater}

After the hull surface floater is finished, from this draw, a surface buoy frame can be made. The distance between the frames is $270 \mathrm{~mm}$ and the thickness is $10 \mathrm{~mm}$. There are 16 for frames on the surface floater and 1 for keel. To make frame and kell using Autodesk Inventor software so that it produces a 3D image which will be analyzed for strength using FEM software. The frame and keel images are shown in figure 2.

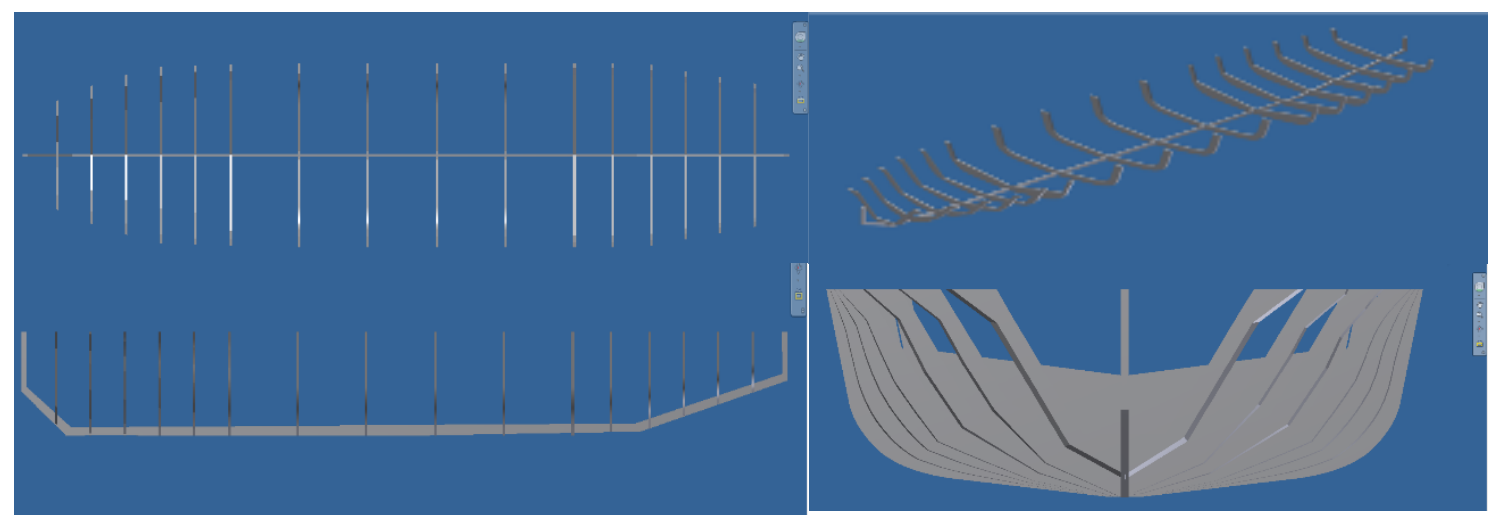

Figure 2. Frame Surface Floater

\section{Finite Element Method/FEM}

The finite element method is widely used in numerical calculation applications of structural strength, both car structures, aircraft structures and ship structures (Nugroho and Pitoyo, 2012). For floating structures (ships), the calculation of strength is required by calculating the maximum stress that occurs, in this case the direct stress on the floating structure. Derivation of the stress and deflection equations with elementary block theory follows the following formula.

$$
\sigma \mathrm{x}=-\frac{M(x) z}{I}
$$

Where:

$\mathrm{z}=$ the distance that the point in question rises to the point $\mathrm{x}$

$\mathrm{I}=$ moment of inertia of the entire cross-section of the ship structure at point $\mathrm{x}$ 
For this paper, to create of elements using the FEM Ansys Workbench software. The surface floater model that has been modeled with the frame and skin is imported into the FEM software for the meshing process. The meshing process is the process of dividing the elements in the model into smaller and finite elements so that a matrix is obtained from this division which will later be used to perform numerical calculations by the FEM software. The meshed surface floater image is shown in Figure 3.

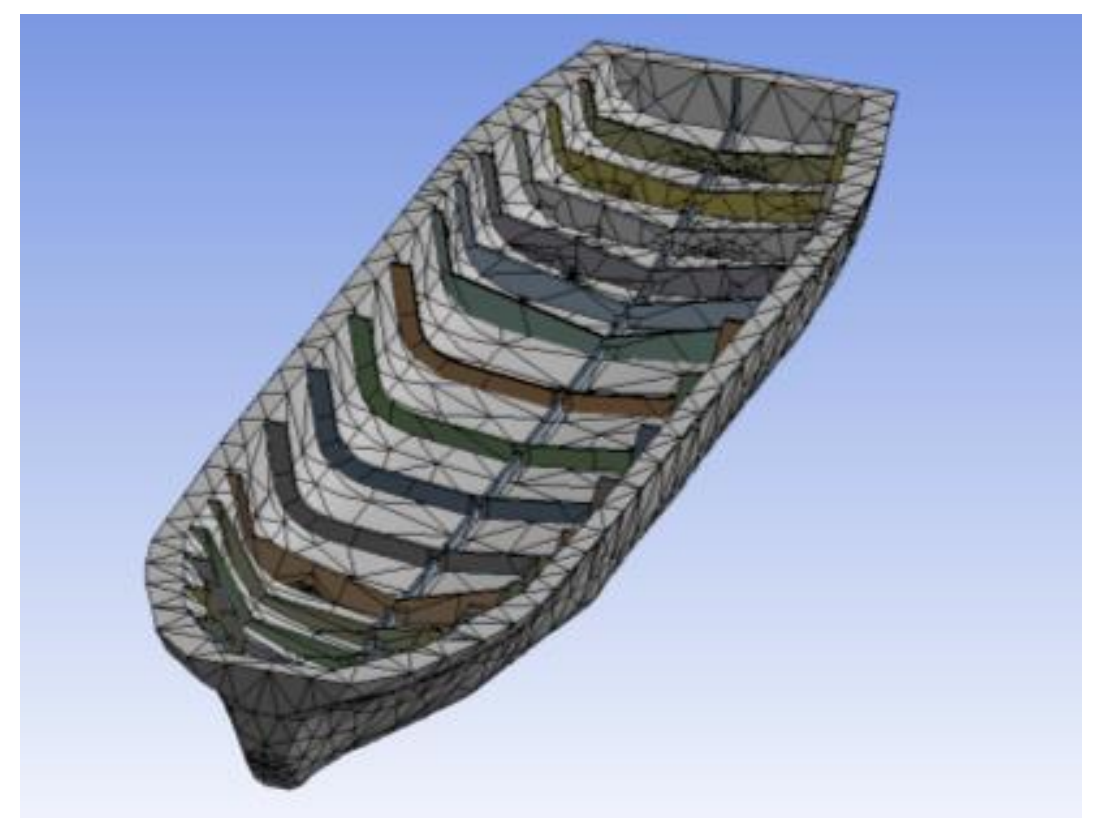

Figure 3. Meshing Surface Floater (Hull\&Frame)

\section{Load for Surface Floater}

Environmental loading applied to the surface floater is divided into two, namely the load due to the weight of the floater which is centrally distributed on the midship of the upper surface and hydrodynamic load which is evenly distributed on the entire lower surface. For the force at the top (weight) using the following formula:

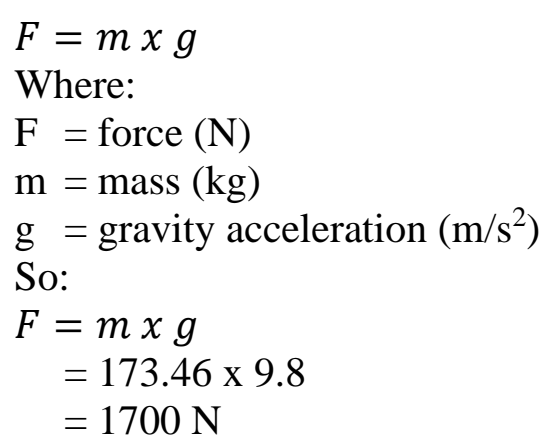

This gravity is used for force input in the FEM software as a force that hits the top of the surface floater shown in Figure 4. 


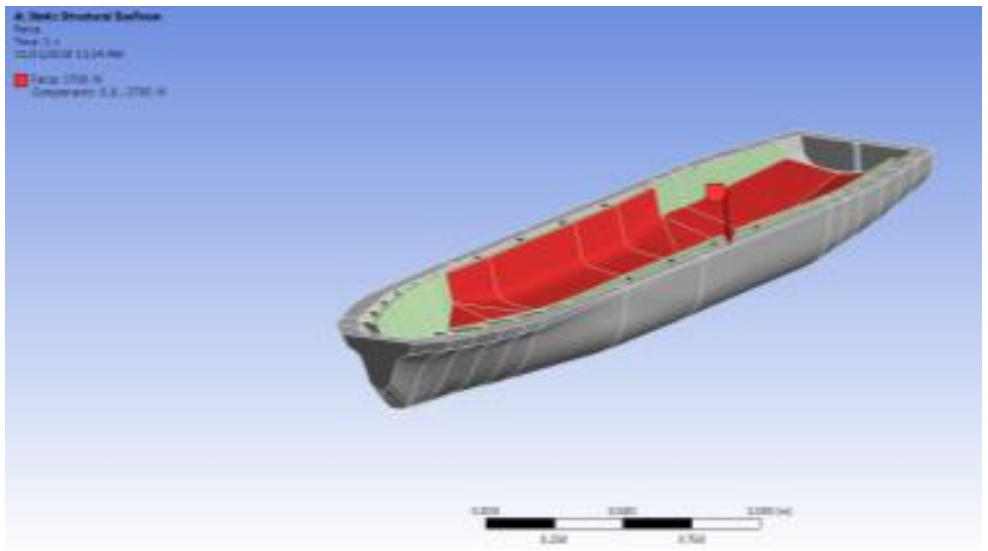

Figure 4. Load Force on Surface Floater

For the force at the bottom (hydrostatic pressure) use the following formula:

$$
\begin{aligned}
& P=\rho \times g \times h \\
& \text { Where: } \\
& \begin{array}{l}
\mathrm{P}=\text { pressure }(\mathrm{Pa}) \\
\rho=\text { sea density }\left(\mathrm{kg} / \mathrm{m}^{3}\right) \\
\mathrm{g}=\text { gravity acceleration }\left(\mathrm{m} / \mathrm{s}^{2}\right) \\
\mathrm{h}=\text { draft surface floater }(\mathrm{m}) \\
\text { sehingga: } \\
\quad=1025 \times 9.8 \times 1.8 \\
\quad=1856.3 \mathrm{~Pa}
\end{array}
\end{aligned}
$$

This hydrodynamic pressure is used for force input in the FEM software on the lower part of the surface flaoter hull shown in Figure 5.

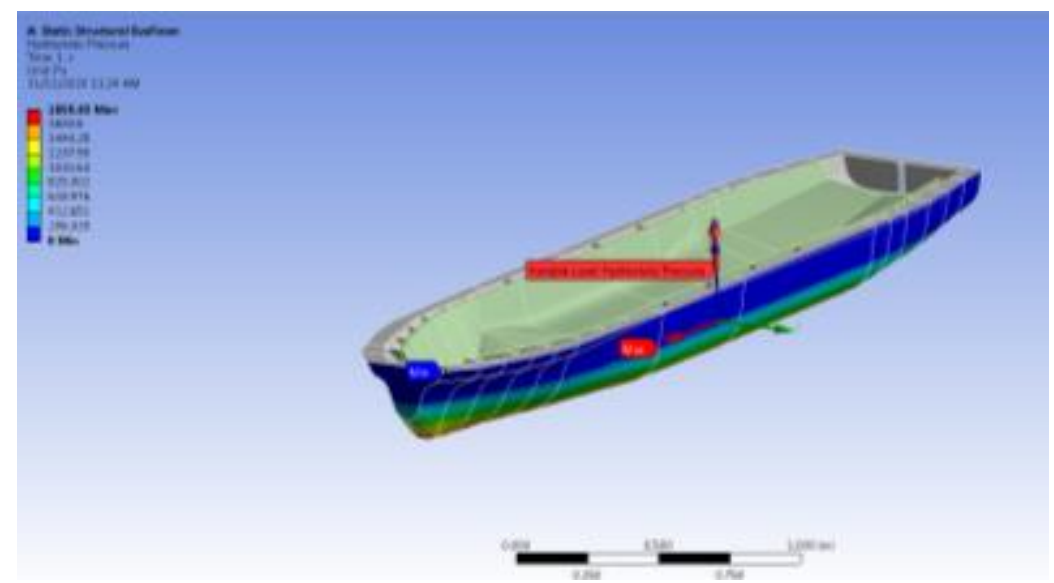

Figure 5. Load Hydrodynamics Pressure on Surface Floater

\section{Results and Discussion}

\section{Maximum Principle Strees \& Shear Stress EVA Foam}

The load is input into the FEM software, for analysis of the strength calculation of the surface floater structure. To determine the strength of the surface floater structure using the maximum principle stress and shear stress parameters generated from numerical calculations. 
For the calculation of the maximum principle stress material parameters for eva foam is $12693 \mathrm{~Pa}$ at maximum and $-17520 \mathrm{~Pa}$ at minimum, while for shear stress for Eva Foam material is $6114.6 \mathrm{~Pa}$ maximum and $-5666.1 \mathrm{~Pa}$ minimum. The results of the calculation of the structural strength of the eva foam material are shown in Figure 6 and Figure 7.

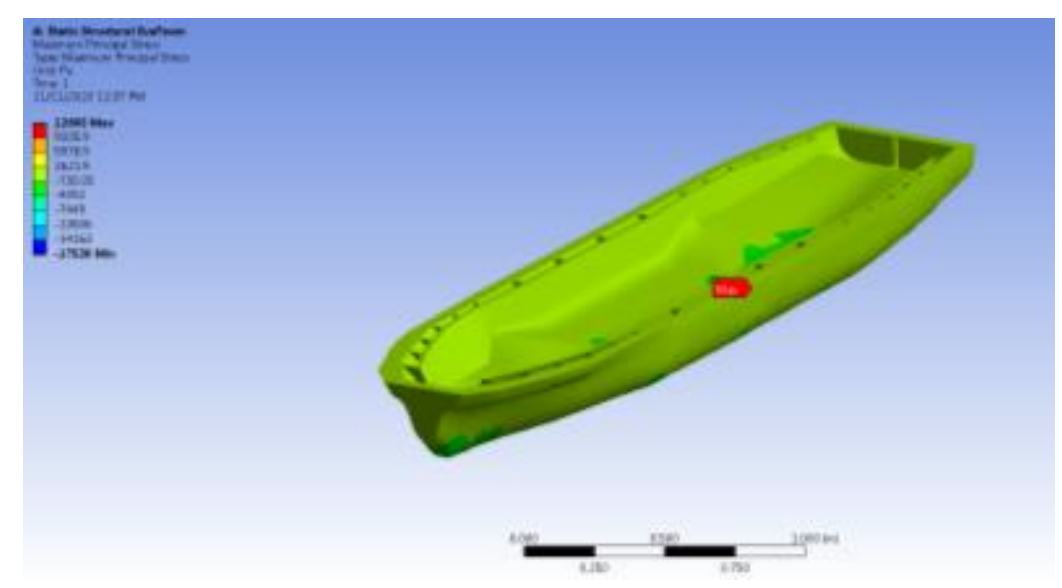

Figure 6. Maximum Principle Stress Eva Foam Surface Floater

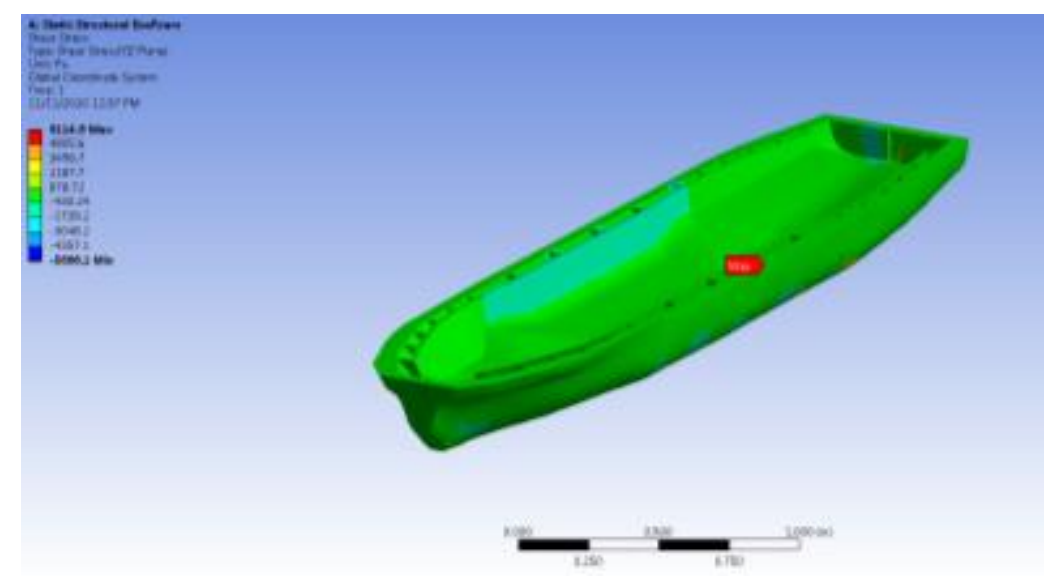

Figure 7. Shear Stress Eva Foam Surface Floater

\section{Maximum Principle Strees \& Shear Stress Fiberglass}

With the same steps for the EVA Foam material, the load is inputted into the FEM software for analysis of the strength calculation of the surface flaoter structure. To determine the strength of the surface floater structure using the maximum principle stress and shear stress parameters generated from numerical calculations. For the calculation of the maximum principle stress parameter for fiberglass material is $11.875 \mathrm{~Pa}$ at maximum and $-8165 \mathrm{~Pa}$ at minimum, while for shear stress for fiberglass material is $6076.6 \mathrm{~Pa}$ maximum and -6317.1 $\mathrm{Pa}$ minimum. The results of the calculation of the structural strength of the EVA foam material are shown in Figure 8 and Figure 9. 


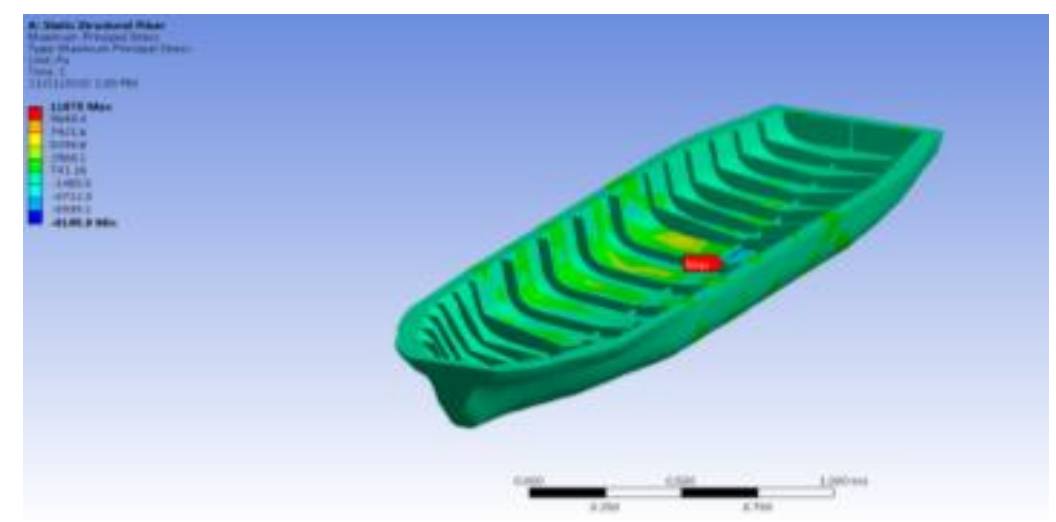

Figure 8. Maximum Principle Stress Fiberglass Surface Floater

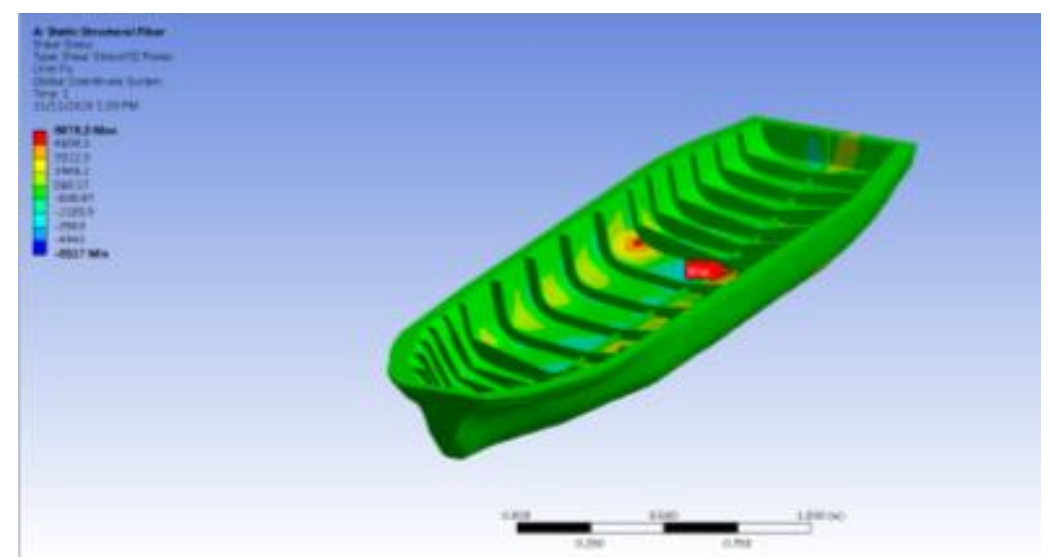

Figure 9. Shear Stress Fiberglass Surface Floater

\section{Discussion}

From the results obtained, we can make a table that contains the simulation results of the calculation of the strength of the surace floater structure using leather material from Eva Foam and Fiberglass. The table for the calculation of the strength of the surface floater structure using Eva Foam is shown in table 5 and the results of the calculation of the strength of the surface floater structure using Fiberglass are shown in table 6.

Table 5. Results of Strength Surface Floater use Eva Foam Material for Skin

\begin{tabular}{ccc}
\hline Parameter & Maximum & Minimum \\
\hline Maximum Principle Stress & $12.693 \mathrm{~Pa}$ & $-17.520 \mathrm{~Pa}$ \\
Shear Stress & $6114.6 \mathrm{~Pa}$ & $-5666.1 \mathrm{~Pa}$ \\
\hline
\end{tabular}

Table 6. Results of Strength Surface Floater use Fiberglass Material for Skin

\begin{tabular}{ccc}
\hline Parameter & Maximum & Minimum \\
\hline Maximum Principle Stress & $11.875 \mathrm{~Pa}$ & $-8.165 \mathrm{~Pa}$ \\
Shear Stress & $6076.3 \mathrm{~Pa}$ & $-6317 \mathrm{~Pa}$ \\
\hline
\end{tabular}

To determine whether the material meets safety standards, it is necessary to analyze the safety factor (SF) for each material used as the surface floater skin. SF calculations according to (Suastika et al., 2019) can be searched using the following formula: 


$$
S F=\frac{\text { Strength }}{\text { Max Stress }}
$$

Use equation number 4, we can calculation SF for each material for every parameter. For Eva Foam material, SF for maximum principle stress is:

$$
\begin{aligned}
& \begin{aligned}
S F & =\frac{\text { Strength }}{\text { Max Stress }} \\
& =\frac{78.000}{12.693} \\
& =6.14
\end{aligned} \\
& \text { and } \text { SF for shear } \\
& \begin{aligned}
S F & =\frac{\text { Strength }}{\text { Max Stress }} \\
& =\frac{78.000}{6.144,6} \\
& =12.6
\end{aligned}
\end{aligned}
$$

and SF for shear stress is:

So for material from Eva Foam, the surface flaoter can be absord loads up to $6 \mathrm{x}$ the loads used in this paper. And for material from Fiberglass, use equations number 4 we can calculate $\mathrm{SF}$ for each parameter, SF for maximum principle stress is:

$$
\begin{aligned}
\text { SF } & =\frac{\text { Strength }}{\text { Max Stress }} \\
& =\frac{3.1 \times 10^{8}}{11.875} \\
& =26
\end{aligned}
$$

and SF for shear stress is:

$$
\begin{aligned}
S F & =\frac{\text { Strength }}{\text { Max Stress }} \\
& =\frac{3.1 \times 10^{8}}{6076.3} \\
& =51
\end{aligned}
$$

So for material from Fibrglass for skin of surface flaoter, the surface floater can be absord loads up to 26x the loads used in this paper. Wave glider now is widely used for exploration of marine resources and marine topography. A wave glider is an unmanned vehicle that combines two bodies (floater and submerged glider) via flexible umbilical cables, which can directly convert the movement of ocean waves into propulsion, and also overcome the need for low energy consumption during the observation period at sea. (Zhang et al., 2020). Wave gliders have been widely researched and published by papers, among others (Olson, 2012) which examines the working principle of the sensors used in wave gliders. In this paper, the wave glider is divided into two parts, namely the subsurface (propulsion unit) which converts the thrust from the up and down movement of ocean waves. The second part is a floater that is connected to the subsurface using an umbilical cable. On the floater there are several electronic equipment including solar power panels, antenna decks, mission payloads, core electronics modules. The floater is made of foam material covered with fiberglass. Wave gliders can be used for various needs, including for surveys, monitoring events, changing buoys and for communication gateways. The conclusion of this paper is the communication architecture wave glider can be used for various needs. A more specific requirement is the ability to send data without debugging (delay) as a result of the environment with minimal changes. 


\section{This research conducted by}

functions as a marine mobile buoy (MMB) which has many potentials uses in the maritime industry and marine research. For the propulsion system, the Suntory Mermaid II system is used, which was first popularized by the Suntory Mermaid Ship. The conclusion of this paper is that the propulsion mechanism as the main mover always produces thrust under any floating body movement conditions, the dynamic model of the propulsion mechanism shows the relationship between the heave movement of the buoy, stiffnes and thrust, for maximum movement of the angle of attack (angle of attack). attack) of the foil that produces the greatest thrust is $0.3 \mathrm{rad}$.

Another paper that discusses wave gliders is Wang et al., (2019) which discusses the use of a wave glider as a wave powered autonomous marine vehicle which consists of a submegerd glider that is connected to a surface floater with a tether connector. In this paper, the study focuses on the movement of a 4 degrees of freedom (4-DOF) mathematical model of the wave glider using the Newton-Eular approach. For horizontal waves using second order wave drift, while for vertical waves using first order wave force. Furthermore, the mathematical equation is used for the calculation of the motion simulation of the wave glider. The results of this paper are the calculation of the movement of the 4-DOF wave glider in various wave conditions and produce several recommendations, including the shorter tether length, which will reduce the resistance of the foil, the weight of the surface float and submarine glider models is made lighter in order to further improve the resistance. the energy the waves produce. Paper that discusses the strength of the ship's structure is (Liu and Guedes Soares, 2020) where the research is focused on the structure of the hull of the ship due to the load or the moment of hogging and sagging movements due to sea waves. The initial approach is to calculate the structural strength of the "cyclic ultimate strength". For numerical calculations using the LS-Dyna software. Numerical analysis on the cyclic ultimate structure considers the bauschinger effect on steel. The Bauschinger effect describes the flow of stress decreasing when the load is reversed. The bauschinger effect is mostly found in conventional steels but also in high strength steels. The conclusion of this study is that ship hull girders have a smaller ultimate strength due to cyclic loads. The value of the difference in ultimate strength of steel that is subjected to cyclic loads and steel that experiences a static load is $10 \%$. And paper is Mujahid \& Priohutomo, (2018) which examines the shear stress on the Bore Hull Mining (BHM) type ship. BHM ships are vessels used to mine rocky materials in rivers. In this paper, the discussion focuses on the shear strength of BHM ships due to the heavy load of the ship. The calculation uses the numerical method with the Finite Element Method (FEM). The results of this paper are that the shear stress at various loading conditions is not suitable or does not meet the criteria set by Internatioanl Maritime Organization (IMO) dan Biro Klasifikasi Indonesia (BKI).

\section{Conclusion}

The conclusion that can be drawn from this paper is the use of materials form Eva Foam and Fiberglass for skin surace floater of wave glider is accordance with exixting rules. This is indicated by the results of safety factor (SF) or each material is greater than 3 . The use of frames with total 16 pieces and for keel 1 piece this is indicated the surface floater can be operated in the sea for draugh $0.18 \mathrm{~m}$.

\section{Acknowledgments}

This author said thanks to Centre for Maritime Industry Engineering Technology (PTRIM) dan Indonesian Hydrodynamic Laboratory (BTH) it has allowed the use of the original license software for Autodesk Inventor, Rhinoceros and Ansys Workbench software to completed of this paper. 


\section{References}

Areias, P., Rodrigues, A., Rabczuk, T., Garção, J., Carvalho, A., 2017. Analysis of experimentally assessed EVA foams with mixed solid-shell elements capable of very large strains. Finite Elem. Anal. Des. 128, 19-31. https://doi.org/10.1016/j.finel.2017.01.003

Atika, R., Raditya, A.E., Marjianto, R.N., 2019. Automatic Tsunami Early Warning System Tersinkronisasi Bmkg Dan Pengeras Suara Tempat Ibadah. Autom. Tsunami Early Warn. Syst. Tersinkronisasi Bmkg Dan Pengeras Suara Tempat Ibadah 3, 30-35. https://doi.org/10.21831/jee.v3i1.26100

Liu, B., Guedes Soares, C., 2020. Ultimate strength assessment of ship hull structures subjected to cyclic bending moments. Ocean Eng. 215, 107685. https://doi.org/10.1016/j.oceaneng.2020.107685

Mujahid, A.S., Priohutomo, K., 2018. Studi Kelayakan Desain Kapal Hisap Tambang. Wave J. Ilm. Teknol. Marit. 12, 81-88. https://doi.org/10.29122/jurnalwave.v12i2.3461

Nugroho, W.H., Pitoyo, P., 2012. Study Numerik Distribusi Tegangan Badan Kapal Berbahan Aluminum. Wave J. Ilm. Teknol. Marit. 6, 1. https://doi.org/10.29122/jurnalwave.v6i1.3318

Olson, R.A., 2012. Communications architecture of the liquid robotics Wave Glider, IFAC Proceedings Volumes (IFAC-PapersOnline). IFAC. https://doi.org/10.3182/20120410-3-pt-4028.00042

Salekeen, S., Jones, D.L., 2007. Fatigue response of thick section fiberglass/epoxy $\begin{array}{llll}\text { composites. } & \text { Compos. } & \text { Struct. } & \text { 79, }\end{array}$ https://doi.org/10.1016/j.compstruct.2005.11.040

Sang, G., Zhu, Y., Yang, G., 2016. Mechanical properties of high porosity cement-based foam materials modified by EVA. Constr. Build. Mater. 112, 648-653. https://doi.org/10.1016/j.conbuildmat.2016.02.145

Shen, W., Yan, R., Luo, B., Zhu, Y., Zeng, H., 2017. Ultimate strength analysis of composite typical joints for ship structures. Compos. Struct. 171, 32-42. https://doi.org/10.1016/j.compstruct.2017.02.008

Suastika, K., Sahlan, Nugroho, W.H., Zubaydi, A., Misbah, M.N., Murdjito, 2019. Fatigue life assessment of waste steel reused as tsunami buoy keel structures: A case study. Int. J. Technol. 10, 700-709. https://doi.org/10.14716/ijtech.v10i4.501

Wang, P., Tian, X., Lu, W., Hu, Z., Luo, Y., 2019. Dynamic modeling and simulations of the wave glider. Appl. Math. Model. 66, 77-96. https://doi.org/10.1016/j.apm.2018.08.027

Xie, H., Liu, F., Tang, H., Liu, X., 2020. Numerical study on the dynamic response of a truncated ship-hull structure under asymmetrical slamming. Mar. Struct. 72, 102767. https://doi.org/10.1016/j.marstruc.2020.102767

Yu, Z., Zheng, Z., Yang, X., Chang, Z., 2016. Dynamic analysis of propulsion mechanism directly drivenby wave energy for marine mobile buoy. Chinese J. Mech. Eng. (English Ed. 29, 710-716. https://doi.org/10.3901/CJME.2016.0317.032

Zhang, J., Chang, Z., Lu, G., Zheng, Z., Zhang, Z., 2020. Analysis of the Dynamic System of Wave Glider with a Towed Body. J. Ocean Univ. China 19, 519-524. https://doi.org/10.1007/s11802-020-4341-4. 